\title{
Hate Crime in the News: The Media's Role in Agenda Setting
}

\author{
Codey J. Collins ${ }^{1, *}$, Douglas A. Orr ${ }^{1}$ and Toralf Zschau ${ }^{2}$ \\ ${ }^{1}$ Department of Criminal Justice, University of North Georgia, Georgia \\ ${ }^{2}$ Department of Sociology \& Human Services, University of North Georgia, Georgia
}

\begin{abstract}
Examining the extant literature on hate crimes shows that there has been an evolutionary process of Hate Crime legislation (HC). Similar to other social movements such as civil rights, the hate crime movement also had various waves which eventually lead to the passage of legislation. By and large, however, HC research has focused on victims and offenders of hate crimes as well as motivations of bias. Moreover, less research has been done on the media's portrayal and coverage of HC. Since the media is a noted influencer in social issues (Culotta, 2002; Quisenberry, 2001), we sought to answer how the news media are reporting incidences of hate crimes - particularly LGBTQ+- and compare them with official crime statistics reported by law enforcement agencies. In order to answer these questions, our research utilized a qualitative content analysis using QSR NVivo 12.0 to identify potential themes and trends which may be overlooked in simple quantitative methods. Our dataset comes from the Hate Crime Index ("ProPublica," 2018), for the month of June 2018. Official FBI data is also utilized for comparison, spanning from 2012 to 2016. Our results suggest that the media reports HC within an overall internal Agenda Setting Orientation. During analysis, two main themes were identified that show the (i) media report both the failures and challenges of law enforcement in dealing with $\mathrm{HC}$ issue and, (ii) that media highlights various best practices some agencies engage in. Limitations and future research directions are discussed.
\end{abstract}

Keywords: Hate crimes, news coverage, criminal justice, social movements, legislation.

\section{INTRODUCTION}

Even though hate crimes may have a long history of occurrence throughout humanity, as many researchers contend, specific attention to these crimes is relatively recent in both US legislation and the criminal justice profession (Culotta, 2002). There have been research studies done on policies surrounding hate crime legislation since this special type of legislation made its debut appearance in the US during the 1980s. These studies have considered the history of social movements such as civil rights and LGBTQ+ movements for their influence in leading to the eventual passage of legislation. Research attention has also been given to victims of hate crimes spanning from simple quantitative analysis of victim demographic characteristics to in-depth qualitative analysis examining the whole breadth and depth of experiences these victims faced. To be certain, victims of hate crimes and their family, friends, and communities have been at the forefront of social movements and have thusly been an integral part of research studies. Similarly, there have been significant studies conducted exploring the offender side of hate crime incidences and, indeed, much research given to the motivations behind acts of hate violence (Iganski and Lagou 2015, Turpin-Petrosino 2015, Walters, Brown and Wiedlitzka 2016).

*Address correspondence to this author at the Department of Criminal Justice, University of North Georgia, Georgia; Tel: +1 (706) 864-1904;

E-mail: E.S.L.Instructor@outlook.com
Studies such as those mentioned above, as well as other early researchers who subscribed to issues of hate as being a crime have contributed to our current day conceptualization of what exactly a hate crime is by providing context and structural/working definitions (Chakraborti and Garland 2012, Garland and Funnell 2016, Grattet and Jenness 2001, Mason 2005, Perry 2003, Walters, Brown and Wiedlitzka 2016). Further, these inquires have contributed to the formation of hate crime categories among law enforcement agencies, particularly the $\mathrm{FBI}$, and provide some guidance on determining if crimes are based on bias vs. non-bias motivations. Little is known, however, about how hate crimes are covered in the news, most specifically relating to sexual orientation and gender identity. Studies do exist that examine news coverage and crime in general and which consider the influence of news coverage on crime rates (Quisenberry, 2001). But LGBTQ+ bias-motivated hate crimes in the media are less studied (Grozelle, 2014; Shively \& Abt Associates, 2005). To fill this gap, our study examines news coverage specifically related to hate crimes motivated by LGBTQ+ bias. We seek to answer how the news media are reporting incidences of hate crimes particularly LGBTQ+- and questions if those news reports align with official crime statistic reported by law enforcement agencies.

\section{LITERATURE REVIEW}

Since issues surrounding hate crime have historically been discussed in a limited way within the realm of official institutions (i.e. legislature and 
enforcement agencies), a coherent and established definition of what exactly a hate crime is, is still in the process of debate and development. It has taken many decades and numerous social stakeholders to contribute to the working definition of hate crimes. Hate crimes have traditionally been described as not necessarily a separate type of crime, but instead are discovered through the commission of another crime wherein the motivation to commit that alreadyestablished crime classification (assault for example) is questioned. If it is believed that the crime was committed with a bias towards or hatred of a person or a group of people who have some form of identity or immutable characteristic opposed to or different from the perpetrator, then the crime may be classified as a hate crime. In legal terms, establishing whether or not a crime has been committed generally necessitates the establishment of an actus reus. The actus reus simply means establishing the facts that a certain event occurred. A person can be liable for a crime in some instances based solely on their actions. Our judicial system however generally likes to also establish the mens rea (mental state / motive) of an individual in order to establish just how much culpability an individual should face for their actions (Meli, 2014). Often, when considering motivations behind committing a crime such as homicide, harsher penalties may be imposed if an individual willfully, intentionally, and with premeditation killed another individual as opposed to some cases where more lenient sentences may be given as is the case when the homicide was an accident, self- defense, or even a heat of the moment event.

While the motivating factor of hate crimes has traditionally been tied to the commission of other already established crime classifications, it no longer has to remain an ancillary thought for prosecutors or the justice system. Early hate crime statutes acted primarily as penalty enhancing mechanisms for already established crimes (Grattet \& Jenness, 2001; Leung, 2018). Today however, some statutes classify hate crime as its own independent crime category with its own respective penalties. As such, in some instances, persons may be found guilty of committing a crime such as assault and its corresponding sentencing, as well as hate crime, and its respective sentencing.

\section{HATE CRIMES: DEFINITION AND EVOLUTION OF A MOVEMENT}

Wide variations in reports on hate crime statistics is a cause for pause. After examining statistics on hate crime as reported across the nation and from various agencies, research points to some reasons why such variations may exist. The main reason for such variation stems from the aforementioned issues of establishing and using a unified definition of what exactly a hate crime is. The hate crime movement has evolved in different directions at varying speeds across different locations throughout the nation. Thus, respective policies and legislation pertaining to hate crimes factor into law enforcement and prosecutorial actions involving hate crimes which naturally affect hate crime statistics. A step in the right direction to help rectify these issues was the Hate Crime Statistics Act (HCSA) of 1990, implemented at the federal level. The adage of 'the squeaky wheel gets the grease' is quite applicable in examining the evolution of hate crime efforts in the United States, which happens to be quite analogous to several other social issues. For instance, Chakraborti (2015) points out that groups who have a collective history of discrimination or stigmatization will -over time- likely engage in social movements which lead to policy changes, as can be seen with the civil rights movement and the creation and passage of the 1968 Civil Rights Act (Boeckmann \& Turpin-Petrosino, 2002; NOLAN III, Akiyama, \& Berhanu, 2002). It is acknowledged, however, that such change for these groups is often either constrained in certain ways and into certain directions, or, afforded greater success, based on the groups respective access to resources, vocalization and energy of members, as well as broader social contexts such as public support and structural factors.

In a social context, many consider the hate crime movement to be an extension of the civil rights era in which historically underrepresented and oppressed minorities began to openly address concerns of their treatment both structurally and culturally. Social organizations for example, such as the Southern poverty Law Center (SPLC) or Anti-Defamation League (ADL), had traditionally worked on broader civil rights and justice equality issues, but the hate crime movement nonetheless found support from these organizations during the 1980s. During the 1980s these and other organizations began to look more specifically at crimes committed against individuals based on motives of bias and hatred (Grattet \& Jenness, 2001). Thanks to these stakeholders, the hate crime movement now has a more unified -though still evolving- definition of hate crime.

Today hate crimes are considered to be crimes committed against an individual because of their race, 
ethnicity, religion, sex, gender identity, sexual orientation, age, disability, and even homelessness (National Coalition for the Homeless, 2014; Tomei \& Cramer, 2016). Not all of these attributes however have been viewed equally nor have seen as long of a history within the hate crime debate as have others. Religion and race are perhaps the oldest and first categories to lead the way in the hate crime arena. Sexual orientation and gender identity came about as a second wave of hate crime reform. The most recent additions to hate crime statutes are categories of homelessness and disability (Grattet \& Jenness, 2001; Levin \& Amster, 2007).

Several acts and legislation have been instrumental in bringing the hate crime movement to its current day platform. In 1994, legislation titled the Violent Crime Control and Law Enforcement Act, provided several expansions to its predecessor, the 1990 HCSA. This 1994 act provided coverage for disabilities discrimination. Advocates within the movement pushed for protections to include not only acts against persons physically but also acts against property, livelihood, and mental \& social wellbeing as well. Advocates argue that much of the violence directed towards individuals resulted not always in physical violence but rather manifested in acts of vandalism, theft, arson, or other forms of property damage. Hate speech of religious, racial, political and other forms of bias was and still are often spray- painted on public and private buildings alike. Churches have historically been the primary target for hate speech and other forms of vandalism or arson. Another act in 1996 called the Church Arson Prevention Act entered the Federal statute which provided for additional punishments to offenders convicted of vandalism or arson of a church if the crime is motivated by religious difference bias or hatred (NOLAN III et al., 2002).

One of the most recent additions to hate crime legislation is The Matthew Shepard and James Byrd, Jr., Hate Crimes Prevention Act of 2009. Even though previous hate crime legislation was enacted federally, prior to this 2009 legislation, federal agencies, primarily the $\mathrm{FBI}$, were limited in their ability to investigate hate crimes across the nation. Beforehand, assistance from the FBI was limited to investigating crimes, even hate crimes, unless other federal crimes had been committed in tandem with the hate crime, such as kidnapping or interstate movement. The 2009 act also expanded the federal definition of what constitutes a hate crime. Federal statute defines a hate crime as "biases of actual or perceived sexual orientation, gender identity, disability, or gender [as well as its original concern for] bias against the victim's race, color, religion, or national origin" (F.B.I., 2018, Hate Crimes, para. 2). This paper will move forward looking specifically at hate crimes involving sexual orientation and gender identity.

\section{HATE CRIMES IN THE NEWS}

Little research has been done concerning hate crimes and their association with media outlets compared to other media and criminal justice-related topics. This section will briefly highlight some research that does exist on hate crimes being portrayed in the news. Previous sections of this paper noted the general influence that media and news media may have on the general population. This section concerns specifically hate crimes and their influences on and potential uses by the criminal justice system. For instance, as media is so pervasive in today's society, our daily routines are subject to a plethora of media exposure. And broadly speaking, many in the criminal justice field would argue that their jobs are often under more scrutiny today than most other professions. Quisenberry (2001) suggests that, "The net effect of media exposure may be to push public officials to treat hate offenses in a more serious manner and, consequently, to apply more severe sanctions to perpetrators" (p.3). Quisenberry posits that media acts as a driving force to sustain police responsibility and professionalism.

On the other hand, while it is generally accepted that media coverage can and does influence police action, not all agree that this driving force is always in a positive direction. Culotta (2002) points out that when certain issues or groups of people get more response from the police due to their coverage in the media, police action may occur sooner or with greater intensity but nonetheless occurs at the cost of others who were already in line for police services. It is suggested that the media can act as an informal advocate and often bring many resources to the table. But if a certain topic or group of people are not the subject of the media's immediate agenda it creates an imbalance of resources and a de facto preferential treatment by the police who feel they must often address issues that received the most exposure.

Even still, others argue that media is an underutilized source of qualitative data for crime (Shively \& Abt Associates, 2005). We indeed argue that news media may provide deeper insights into the issue of a crime than official government reports. This 
argument considers that governmental reports are in nature designed to be more quantitatively oriented and therefore unable to capture the totality of the experiences that a crime victim may have in a given incident much less broadened to incorporate other incidences or life histories. Likewise, some victims may be more willing and open to disclose certain incidents to media and nongovernmental organizations than directly to the police. The government already deals in big data and, from the legalistic framework, they must typically only consider the facts surrounding a particular incident, particularly in terms of statistical reports. Usually, only anecdotal data are reported.

While some argue that media is a good source of qualitative data, still others point to issues of omission regarding the media coverage of hate crimes. For example, Grozelle (2014) notes that media, in general, views a crime from a sensationalist perspective, and, as such, may often follow suit in reporting only issues that will gain viewership in any given era. Specifically, in the context of sexual orientation and gender identity, Grozelle (2014) further argues that news media fails to report issues in a more comprehensive way namely because they often fail to understand the nuances of sexual orientation and gender identification. Whether it is from a deliberate choice in terms of limiting the time and effort needed to explain the nuances and reporting or whether it is truly a lack of knowledge, it has been found that any sexual orientation and gender identity news stories are simply lumped together under a heading of 'gay' issues, which, leaves out a store of details and realities as experienced by victims of these offenses (Grozelle, 2014).

\section{METHODS}

\section{Dataset}

The Hate Crime Index dataset constitutes a collaborative effort between ProPublica, a Pulitzer-prize winning news organization that describes itself as a "non-profit newsroom that produces investigative journalism in the public interest" ("ProPublica," 2018) and Google News Lab. The dataset contains media reports, collected by Google News, about hate crimes and bias incidents beginning in February 2017. In this study, only hate-crime-related news reports from June $1^{\text {st }}$ to June $30^{\text {th }}, 2018$ were analyzed.

\section{Coding and Data Analysis Strategies}

The coding process involved two stages: Stage I: General Analysis of Hate Crime News Coverage. A deductive coding scheme was developed partially informed by the FBl's Universal Crime Reporting (UCR's) hate crime incidence and offense reporting categories (F.B.I., 2018). The final coding scheme included three major coding categories: story content (single-bias incidence, multiple bias incidence, other content), hate crime motivator (race/ethnicity/ancestry, religion, sexual orientation, disability, gender identity, gender, other), and nature of the hate crime (crime against person, crime against property, crime against society). Using this coding scheme, 478 news reports from the Hate Crime Index dataset were coded and analyzed in QSR NVivo 12.0. During stage II of the analysis, 96 of the 478 media reports that focused on hate crimes involving cases of sexual orientation and gender identity were re-examined and subjected to a more rigorous in-depth qualitative data analysis. The goal of this second wave of coding was to better understand how news organizations discuss these hate crimes. Particular care was given to how the news portrayed the police response to purported incidences of hate crime as well as noted attention to any forms of agenda-setting.

\section{RESULTS AND DISCUSSION}

This section will outline the results from our research and serve to inform a discussion regarding the analysis. This section will also utilize block quotes taken directly from news articles. These quotes capture two main themes identified during coding. The two main themes that appeared, were categorized as an 'Agenda Setting Orientation'. The $1^{\text {st }}$ Theme is Challenges in Implementation of Hate Crime Laws. The $2^{\text {nd }}$ Theme is Showcasing Best Practices of Law Enforcement. Keeping these themes in mind let us discuss the results of the first wave of analysis. Looking at Table 1, we see that $77 \%$ of all news articles we examined reported incidences based only on a single bias. Only $2.3 \%$ of articles reported on incidences involving more than one bias as a motivator for the offender's hate crime. The other category comprises $20.7 \%$ of the news articles which did not report specific incidences but rather for stories merely discussing topics of hate crime such as legislation, community involvement and response, or anniversaries of past incidences of hate crime. The hate crime motivator section of Table 1 indicates that $60 \%$ of the news articles involved racial, ethnic, or ancestry bias motivated crime. Only $12.8 \%$ of crimes mentioned were based on religious bias while slightly more cases involved sexual orientation hate crime at $15.9 \%$. Disability comprised only $1 \%$ of the news stories and, 
interestingly, as we consider Table $\mathbf{2}$ we see that the disability category drops to $0 \%$. This suggests that there were no direct incidents involving disability hate crime from the news articles, and that disability hate crime was the least among the articles discussing the topic of hate crime. Gender hate crime comprised $1.7 \%$ while gender identity comprised $7.5 \%$ of all articles.

Table 1. Hate Crime as Captured in the News News Coverage In Percent

\section{Story Content}

Single-Bias Incidences

Multiple Bias Incidences

Other

$77.0 \%$

$2.3 \%$

$20.7 \%$

\section{Hate Crime Motivator}

Race/Ethnicity/Ancestry

$60.0 \%$

Religious Bias

$12.8 \%$

Sexual Orientation

$15.9 \%$

Disability

$1.0 \%$

Gender

$1.7 \%$

Gender Identity

$7.5 \%$

Other

N
Note: Percentages here differ from Table 2. because of a change in $\mathrm{N}$. Table 1. captures crime incidences, as well as discussion articles on $\mathrm{HC}$ incidences.

According to the F.B.I. (2018), 15,254 law enforcement agencies participated in collecting and reporting hate crime statistics in 2016. Interestingly, however, only 1776 agencies reported having at least one incident of hate crime. From those agencies, there were a total of 6063 hate crime incidences. A majority of those $(57.5 \%)$ were based on motivations of racial, ethnic, or ancestry bias. Religious bias accounted for $21 \%$, sexual orientation bias $17.7 \%$, while only $2 \%$ of instances were motivated by gender identity bias, and $1.2 \%$ motivated by disability bias respectively (Table 2 ). Briefly considering the data broken down by states, we can see that for the 2016 reporting period, Georgia had the 11th highest number of agencies participating in the hate crime statistics program. However, of the 493 agencies in Georgia participating in the program, only six reported any incidents of hate crime, for a total of only 39 incidences. Comparatively, the neighboring state of Florida had only 46 reporting agencies in the same period, but 44 of those agencies reported a total of 96 hate crime incidences. For perspective, these two states had approximately the same population to serve, with Florida having 8,988,095, to Georgia's 8,216,137.
For our last comparison, we consider Washington state. During the 2016 reporting period, Washington had 253 agencies participating in the program with only 80 agencies reporting incidences. However, there were a total of 387 instances reported. Their population was similar to Georgia, having 7,282,106 (F.B.I., 2018). Given such a wide variance in the number of hate crimes reported between otherwise relatively similar terms, one can only imagine why such discrepancies are present. Others have noticed similar disparities. Meli (2014) reports that "The South is particularly suspect in this respect, as that region has the second-highest crime rate of the four U.S. regions but reports the lowest number of hate crimes" (p. 936). Despite the nonlinear evolution of the hate crime movement along with its inconsistent momentum, Parris and Scheuerman (2015) find that "As more time passes and hate crime policies become institutionalized, states will tend toward homogenization, increasing the likelihood of all states passing similar policies" (p.234). Statistics collected from the FBI's hate crime statistics reporting program for the past five consecutive years are outlined in Table 2. Over this five-year period, we can determine that there are only minor distinctions with reporting trends. Even more interesting, however, is that the news data collected during this study is strikingly similar to the official reporting, even though the news data is from a single month in 2018 [with 386 sources] while the official FBI statistics spans five full years [with an average 5816 cases in a single year].

Similar to the patterns of percentages of the news data in Table 1, news data in Table 2 maintains these patterns of percentages even though 92 articles have been excluded from this portion of analysis. These 92 cases were excluded as they did not meet the requirements needed to have a comparative analysis of the FBl's data collection methodology. Simply, these 92 articles did not have specific reports of incidences, while the FBI's data included only incidences. Among both news coverages and FBI data, we can see that the types of crimes being reported are very similar with single-bias incidences accounting for the vast majority of cases. The news media reported on average approximately $10 \%$ higher incidences of racial, ethnic, or ancestry bias than did the FBI.

Next is religion. The FBI data on average reported approximately $7 \%$ higher for these cases than did the media. Sexual orientation bias incidences however are reported nearly identically between the news media and the $\mathrm{FBI}$ reports with reporting on gender incidences along the same parallel. While actual 
Table 2. Hate Crime: News Coverage and Official FBI Statistics

News Coverage FBI FBI

In Percent

$2012 \quad 2013$

Type of Hate Crime

Single-Bias Incidences

Multiple Bias Incidences

$92.7 \%$
$7.3 \%$

$99.9 \%$

$99.9 \%$

$99.7 \%$

$99.5 \%$

$99.1 \%$

Hate Crime Motivator

Race/Ethnicity/Ancestry

Religion

\begin{tabular}{cccccc}
$92.7 \%$ & $99.9 \%$ & $99.9 \%$ & $99.7 \%$ & $99.5 \%$ & $99.1 \%$ \\
$7.3 \%$ & $0.1 \%$ & $0.1 \%$ & $0.3 \%$ & $0.5 \%$ & $0.9 \%$ \\
& & & & & \\
$68.9 \%$ & $59.8 \%$ & $59.6 \%$ & $60.7 \%$ & $56.9 \%$ & $57.5 \%$ \\
$13.2 \%$ & $19.0 \%$ & $20.8 \%$ & $18.6 \%$ & $21.4 \%$ & $21.0 \%$ \\
$17.3 \%$ & $19.6 \%$ & $17.4 \%$ & $18.6 \%$ & $18.1 \%$ & $17.7 \%$ \\
$0.0 \%$ & $1.6 \%$ & $1.4 \%$ & $1.5 \%$ & $1.3 \%$ & $1.2 \%$ \\
$0.3 \%$ & $\mathrm{n} / \mathrm{a}$ & $0.3 \%$ & $0.6 \%$ & $0.4 \%$ & $0.5 \%$ \\
$7.5 \%$ & $\mathrm{n} / \mathrm{a}$ & $0.5 \%$ & $1.8 \%$ & $2.0 \%$ & $2.0 \%$ \\
$76.2 \%$ & $59.1 \%$ & $63.9 \%$ & $63.1 \%$ & $65.1 \%$ & $64.5 \%$ \\
$10.8 \%$ & $39.6 \%$ & $43.5 \%$ & $43.1 \%$ & $41.3 \%$ & $44.7 \%$ \\
$52.3 \%$ & $66.1 \%$ & $55.4 \%$ & $56.4 \%$ & $57.5 \%$ & $54.2 \%$ \\
$35.1 \%$ & $0.6 \%$ & $0.6 \%$ & $0.3 \%$ & $0.7 \%$ & $0.7 \%$ \\
$1.6 \%$ & $0.8 \%$ & $0.6 \%$ & $0.1 \%$ & $0.4 \%$ & $0.4 \%$ \\
$15.1 \%$ & $37.9 \%$ & $35.0 \%$ & $36.1 \%$ & $34.0 \%$ & $34.4 \%$ \\
$69.5 \%$ & $74.8 \%$ & $73.6 \%$ & $73.1 \%$ & $72.6 \%$ & $75.9 \%$ \\
$30.4 \%$ & $25.2 \%$ & $26.4 \%$ & $26.9 \%$ & $27.4 \%$ & $24.1 \%$ \\
$0.0 \%$ & $3.0 \%$ & $1.1 \%$ & $0.8 \%$ & $0.9 \%$ & $1.1 \%$ \\
386 & 5796 & 5928 & 5479 & 5818 & 6063 \\
\hline
\end{tabular}

Sexual Orientation

Disability

Gender

Gender Identity

Crimes Against Person

Intimidation

Assault/Aggravated Assault

Murder/Rape

Other

Crimes Against Property

Damage/Vandalism/Destruction

Robbery/Theft/Burglary/Arson/Other

Crimes Against Society

$\mathbf{N}$

386

Note: FBI data from 2012 to 2016 come from the FBI's Uniform Crime Reporting Program (UCR)

https://ucr.fbi.gov/hate-crime

incidences of disability hate crime were not captured in the news media data, the FBI data reported nearly on average $2 \%$ of cases involving disability bias. Gender identity hate crime was reported nearly five times more in the news articles than in $\mathrm{FBI}$ reporting.

On average, the total crimes against persons were reported approximately $13 \%$ less on the $\mathrm{FBI}$ reports than from the news media. Crimes of intimidation were reported nearly 3 times as much in the official reports than reported in the news media. Incidences of assault, however, were reported quite similarly by both the media and official reports. Murder incidences were disproportionately reported in the media (highly inflated) than through FBI reports. For instance, the media reported murder associated with hate crimes at $35.1 \%$ compared to official $\mathrm{FBI}$ reports of only $0.6 \%$, the largest gap from any Media vs FBI reports from our sample. Overlapping incidences may account for some of this disparity while some researchers would argue that sensationalism in the media would account for more coverage of hate crime murder incidences (Grundlingh 2017, Husselbee and Elliott 2002, Wong and Harraway 2020).
Crimes against property are reported nearly twice as much in the official reports than in the news media. But the subcategories of hate-motivated property crime are similar between the two sources and report similar findings of both vandalism/damage/destruction, and robbery/theft/burglary/arson and others. Categories of crimes against society are not portrayed by the media in this data set but the $\mathrm{FBI}$ reports approximately $1 \%$ of this type of incident.

Turning now to the second wave of data analysis and the qualitative coding of 69 news articles reporting sexual orientation and gender identity biases, we discuss the two main themes discovered. First, the overall orientation of the media is described as an agenda-setting orientation. The first and perhaps slightly more prevalent theme to arise were articles pertaining to the Challenges in Implementation of Hate Crime Laws. The second main theme present during coding showed that many news articles were Showcasing Best Practices of Law Enforcement. Some readers may consider the first theme to be quite confrontational if reading those news articles and indeed some articles explicitly considered law 
enforcement more positively in their ability at policing. However, these and other traits can be captured and labeled under the theme of Challenges in Implementation of Hate Crime Laws. On the other hand, plenty of articles described the help law enforcement gave to not only victims of hate crimes but also in working with and assuring the community at large of their policing efforts.

Some jurisdictions do not have hate crime laws and, therefore, news articles may on occasions unjustly described the police as not taking action on hate crimes. As we mentioned previously in our paper, crime legislation is not uniform across the nation. Perhaps then the topic of protection from hate crime is a takenfor-granted view of the public and media in general. The following section will list block quotes derived from the news articles that capture the respective themes of challenges as well as best practices.

\section{Qualitative Quotes: Media's Agenda Setting Orientation}

Grozelle (2014) notes that Mass Media is (i) part of the culture, (ii) has the capacity and potential to Influence and shape social issues and movements, (iii) and often does act as a social force for advocacy. Our research seems to confirm this description of media and posits that our analysis shows the attempts of media to be influential in social issues, in our case, specifically sexual orientation and gender identity. We argue that by their support for the LGBTQ+ cases of hate crime as portrayed in our analysis, they are continuing to advance their broader agenda of supporting equality. "We must ensure we all work together to put an end to hate, and send a clear message of unity and solidarity" (Pozarycki, 2018, para. 8).

Theme 1 and 2 seem to indicate that the media does intend to shape public opinion and directly or indirectly advance the interests of the LGBTQ+ community by (1) bringing attention to the failures/challenges in trying to implement federal hate crime laws and (2) by showing how different law enforcement agencies try to overcome these challenges.

\section{Theme 1: Challenges in Implementation of Hate Crime Laws}

This first quote highlights that there may still be hesitation among prosecutors to utilize enhanced penalties provided by hate crime legislation. Some argue that such hesitation stems from the aforementioned issue of having a unified definition of hate crime and the remaining difficulties of determining when an incident is committed on a bias motivation (Baker Jr 2000, Goldberger 2004, Jenness and Grattet 1996, Nearpass 2002). Officers and legislators are not doing enough to respond to issues facing LGBTQ+ movement.

Hesitation to pursue the enhanced penalties provided by Hate Crime Legislation.

[P]rosecutors decided against pursuing the battery counts, and the suspects have since bailed out of the Clark County Detention Center, records show. It wasn't immediately clear why the battery charges weren't pursued, and prosecutors could not be reached for comment...(TorresCortez, 2018: para. 4-5).

The second and third quotes shows that the police may also be hesitant to act within the authority given by hate crime legislation. Some argue that this hesitation may be due to a lack of training and lack of understanding of the hate crime laws that do exist much less the broader hate crime movement (Jenness and Grattet 2001, Mason et al. 2017, McVeigh, Welch and Bjarnason 2003). These quotes also highlight that, since there is a perceived lack of police response, victims believe they must seek help from other sources. The fourth quote captures both the frustration of a community along with the social, political, and legal balancing act with which law enforcement agencies must contend.

Perception of the victim. Complaints not being taken seriously.

After filing numerous police reports, the Los Angeles Police Department is now investigating Gierach's neighbors. But Gierach would rather not turn to the police to end the harassment - or, he'd rather not need to turn to the police. (Braslow, 2018:para. 13)

Perception by the victim that nothing was truly being done about the incident. Sought help from other sources, primarily social media.

A Battle Creek man turned to social media after he says he was the victim of a hate crime. Derrick Kilbourn, 24, said he was 
shocked that a gay man would be harassed and assaulted in 2018, but he also said he felt like nothing was being done about it. So, Kilbourn sat at his kitchen table Monday to tell Facebook what he experienced Sunday night. (Gray, 2018:para. 1-3)

Plethora of difficulties faced by the CJ system in terms of Hate Crimes. Human nature is not uniform, and there are seldom clear-cut motivations.

[T] he FBI, which handled the investigation of the terrorist attack, never classified the attack as a hate crime. Prosecutors who later tried unsuccessfully to hold Mateen's widow, Noor Salman, responsible for the attack never explicitly argued homophobia as a motive in the shooting. The Pulse shooting today may be remembered as an historic assault on an LGBT community safe haven, but law enforcement officially settled on the conclusion that Pulse served as a random soft target. Plenty of legal voices and hate-crime experts disagree, and consider hate an obvious factor in the attack. Why then does it lack formal recognition as such? That may have much to do with the difficulty that comes with nailing down motive, a central element to classifying crimes of hate, especially when criminals don't live to see prosecution. (Ogles, 2018: para. 5)

\section{Theme 2: Showcasing Best Practices of Law Enforcement}

The following three quotes express the theme that some agencies are engaged in best practices and that the media is reporting hate crimes in such a way that it promotes these best practices for other agencies to model. Particularly, this theme stresses that the majority of law enforcement officers consider equal protection to be a key principle in their job. Police in many jurisdictions are trying to take hate crime laws seriously and actively seek ways to implement them in their community. For example, the third quote shows that even though a jurisdiction may not have a crime legislation this department reached out to the FBI and requested assistance in investigating a case in order to potentially charge federal hate crime statutes. This indicates at least a modest effort on the part of a local agency to take hate crime seriously whether it is technically a crime in their jurisdictions' book or not.
Acknowledgment of local officials of the need for focused attention toward issues facing the LGBTQ+ community.

Something like this signals how important it is that even though we don't have sufficient hate crime legislation in the state of Texas, we can work at the city level so that these crimes aren't treated like any old property damage," she said. Before she learned of the vandalism, Armintor had planned to contact Denton police to discuss the possibility of establishing a task force designed to work with the LGBTQ community (Jesse, 2018: para. 18-19).

Support from the local Chief law enforcement officer. Active engagement with the LGBTQ+ community and show of support for equality of protection under the law.

Chief Carmen Best@carmenbest. Great
talking to @AlexRozierK5 and
@dougdKING5 this morning about
upcoming \#SeattlePride festivities. It's
going to be a great weekend! (Public
Affairs, 2018: para. 3)

Limited effectiveness of Federal Hate Crime Laws... not universally implemented at state or local levels... yet in some jurisdictions there is a willingness and effort of police to seek help from other agencies in order to file the most applicable charges. Local agency support for Hate crime legislation even though there are no local statutes for hate crimes.

As the State of Arkansas has no statute covering crimes of this nature, commonly referred to as hate crimes, there is no mechanism at the state level for officers or prosecutors to consider additional charges or enhancements," Foster said. "Such statutes do exist at the Federal level. .... Rogers police contacted the FBI on Friday for assistance with the investigation "specifically to review the case for violation of any of the Federal hate crime statutes, Foster said" (Raache, 2018: para. 3-4).

In summation, these quotes highlight the effect that media may have on the reader. We argue that the Media acts as a check and balance to many social issues, even police action. This conclusion is reached 
based on the analysis that lends itself to the notion that the news media highlights and reports on both the shortcomings of police and legislation as well as the positive impacts that the police and crime legislation has on society.

\section{CONCLUSION}

In conclusion, this paper develops through first examining the extant literature on hate crimes and highlighting the evolutionary process of hate crime legislation. Similar to other social movements such as civil rights, so too have variants of the hate crime movement contributed to the eventual passage of legislation. There has been much research given to victims of hate crimes as well as to offenders and their motivations for committing hate crimes. However, less research has been done on the media's portrayal and coverage of hate crimes. Since the media is a noted influencer in social issues (Culotta, 2002; Quisenberry, 2001), we sought to answer how the news media are reporting incidences of hate crimes -particularly LGBTQ+- and compare them with official crime statistics reported by law enforcement agencies. While other forms of hate crime have a more established history and generally receive attention quite readily, such as race and religion (Grattet \& Jenness, 2001; Levin \& Amster, 2007; Tomei \& Cramer, 2016), this author felt that sexual orientation and gender identity are well placed (both in the natural line-up in the $\mathrm{HC}$ evolutionary development, as well as in the actively driven broader social context and current climate) to receive much-needed attention and research in the $\mathrm{HC}$ arena. In order to answer these questions and to determine if the media could be a potential driving force to sustain police responsibility and professionalism in the areas of LGBTQ+ hate crime, our research utilized a qualitative content analysis to identify potential themes and trends which may be overlooked in simple quantitative methods. Our results suggest that the media does likely have an influencing effect on police response to hate crimes and that the media acts as a check and balance to many social issues. By highlighting key quotes found during our analysis, themes were identified that suggest media reported on both the failures and challenges of law enforcement in dealing with the hate crime issue as well as showing various best practices in which some agencies engage.

Those wishing to conduct similar research in the future should likewise seek data sources beyond the conventional cut and dry quantitative reporting.
Certainly, those types of research efforts and means are needed in order to provide tremendous benefits to our field. However, as this research indicates, utilizing mere news reports may identify colorful themes for further interest. For one, future researchers should question why a limited one-month data set of news reports on hate crime parallels very similarly to a fiveyear data set of quantitative official reports. Likewise, since our research identified that some in society have concerns with police enforcement of hate crime laws and, since a theme showing identifiable implementation issues for law enforcement officers arose, future research should also look into how policies can address these implementation issues (Boeckmann \& Turpin-Petrosino, 2002; Chakraborti, 2009, 2015).

\section{REFERENCES}

Baker Jr, John S. 2000. "United States V. Morrison and Other Arguments against Federal Hate Crime Legislation." BUL Rev. 80:1191.

Boeckmann, R. J., \& Turpin-Petrosino, C. (2002). Understanding the harm of hate crime. Journal of social issues, 58(2), 207-225. https://doi.org/10.1111/1540-4560.00257

Braslow, S. (2018). Gay L.A. Veteran Assaulted by Neighbors. Retrieved from https://thepridela.com/2018/06/gay-l-aveteran-assaulted-by-neighbors/

Chakraborti, N. (2009). Crimes Against the "Other": Conceptual, Operational, and Empirical Challenges for Hate Studies. Journal of Hate Studies, 8(1), 9-28. https://doi.org/10.33972/jhs.66

Chakraborti, N. (2015). Re-thinking hate crime: Fresh challenges for policy and practice. Journal of interpersonal violence, 30(10), 1738-1754. https://doi.org/10.1177/0886260514548581

Chakraborti, Neil and Jon Garland. 2012. "Reconceptualizing Hate Crime Victimization through the Lens of Vulnerability and 'Difference'." Theoretical Criminology 16(4):499-514. https://doi.org/10.1177/1362480612439432

Culotta, K. A. (2002). Does the motive fit the crime? Victim, police, and prosecutor decision making in Chicago hate crime cases in 2000. (3080268 Ph.D.), University of Maryland, College Park, Ann Arbor.

F.B.I. (2018). Hate Crimes. What We Investigate Retrieved from https://www.fbi.gov/investigate/civil-rights/hate-crimes

Garland, Jon and Corinne Funnell. 2016. "Defining Hate Crime Internationally: Issues and Conundrums." The Globalisation of Hate: Internationalising Hate Crime:15-30. https://doi.org/10.1093/acprof:oso/9780198785668.003.0002

Goldberger, David. 2004. "The Inherent Unfairness of Hate Crime Statutes." Harv. J. on Legis. 41:449.

Grattet, R., \& Jenness, V. (2001). The birth and maturation of hate crime policy in the United States. American Behavioral Scientist, 45(4), 668-696. https://doi.org/10.1177/00027640121957420

Grattet, Ryken and Valerie Jenness. 2001. "The Birth and Maturation of Hate Crime Policy in the United States." American Behavioral Scientist 45(4):668-96. https://doi.org/10.1177/00027640121957420

Gray, B. (2018). Car window punched out in Battle Creek; police investigate hate crime. Retrieved from http://cw7michigan.com/news/local/car-window-punched-outin-battle-creek-police-investigate-hate-crime 
Grozelle, R. (2014). The Meaning of Murder-Newspaper Framing of Hate Crimes Against Lesbians. (1527099 M.A.), University of Ontario Institute of Technology (Canada), Ann Arbor.

Grundlingh, Lezandra. 2017. "Identifying Markers of Sensationalism in Online News Reports on Crime." Language Matters 48(2):117-36. https://doi.org/10.1080/10228195.2017.1341543

Husselbee, L Paul and Larry Elliott. 2002. "Looking Beyond Hate: How National and Regional Newspapers Framed Hate Crimes in Jasper, Texas, and Laramie, Wyoming." Journalism \& Mass Communication Quarterly 79(4):833-52. https://doi.org/10.1177/107769900207900405

Iganski, Paul and Spiridoula Lagou. 2015. "Hate Crimes Hurt Some More Than Others: Implications for the Just Sentencing of Offenders." Journal of interpersonal violence 30(10):1696718.

https://doi.org/10.1177/0886260514548584

Jenness, Valerie and Ryken Grattet. 1996. "The Criminalization of Hate: A Comparison of Structural and Polity Influences on the Passage of "Bias-Crime" Legislation in the United States." Sociological Perspectives 39(1):129-54. https://doi.org/10.2307/1389346

Jenness, Valerie and Ryken Grattet. 2001. Making Hate a Crime: From Social Movement to Law Enforcement: Russell Sage Foundation.

Jesse, A. (2018). Anti-gay vandalism on Denton garage spurs residents to rally for LGBTQ charity. Retrieved from https://www.dallasnews.com/news/lgbt/2018/06/19/anti-gay-

LEGISLATION. Research in Social Movements, Conflicts \& Change, $38,231-257$

Leung, M. (2018). Points of departure: re-examining the discursive formation of the Hate Crime Statistics Act of 1990. Patterns of Prejudice, 52(1), 39-57. https://doi.org/10.1080/0031322X.2018.1429357

Levin, B., \& Amster, S.-E. (2007). Making Hate History: Hate Crime and Policing in America's Most Diverse City. American Behavioral Scientist, 51(2), 319-348. https://doi.org/10.1177/0002764207306062

Mason, Gail, JaneMaree Maher, Jude McCulloch, Sharon Pickering, Rebecca Wickes and Carolyn McKay. 2017. Policing Hate Crime: Understanding Communities and Prejudice: Taylor \& Francis. https://doi.org/10.4324/9781315696508

Mason, Gail. 2005. "Hate Crime and the Image of the Stranger." British journal of criminology 45(6):837-59. https://doi.org/10.1093/bjc/azi016

McVeigh, Rory, Michael R Welch and Thoroddur Bjarnason. 2003. "Hate Crime Reporting as a Successful Social Movement Outcome." American Sociological Review:843-67. https://doi.org/10.2307/1519748

Meli, L. (2014). Hate Crime and Punishment: Why Typical Punishment Does Not Fit the Crime. U. III. L. Rev., 921.

National Coalition for the Homeless. (2014). Vulnerable to Hate: A Survey of Hate Crimes and Violence Committed against Homeless People in 2013. Retrieved from Washington, D.C.: http://nationalhomeless.org/wp-content/uploads/2014/06/ Hate-Crimes-2013-FINAL.pdf
Nearpass, Gregory R. 2002. "The Overlooked Constitutional Objection and Practical Concerns to Penalty-Enhancement Provisions of Hate Crime Legislation." Alb. L. Rev. 66:547.

Nolan III, J. J., Akiyama, Y., \& Berhanu, S. (2002). The Hate Crime Statistics Act of 1990: Developing a method for measuring the occurrence of hate violence. American Behavioral Scientist, 46(1), 136-153. https://doi.org/10.1177/0002764202046001009

Ogles, J. (2018). Why Does the FBI Refuse to Call the Pulse Massacre a Hate Crime? Retrieved from https://www.advocate.com/crime/2018/6/11/why-does-fbirefuse-call-pulse-massacre-hate-crime

Parris, C. L., \& Scheuerman, H. L. (2015). How Social Movements Matter: Including Sexual Orientation in State-Level Hate Crime https://doi.org/10.1108/S0163-786X20150000038008

Perry, Barbara. 2003. "Where Do We Go from Here? Researching Hate Crime." Internet journal of criminology (IJC).

Pozarycki, R. (2018). Man assaulted on Jackson Heights street in possible hate crime just hours after Queens Pride Parade. Retrieved from https://qns.com/story/2018/06/04/manassaulted-jackson-heights-street-possible-hate-crime-justhours-queens-pride-parade/

ProPublica. (2018). Retrieved from https://www.propublica.org/about

Public Affairs. (2018). Getting Ready for PRIDE, More Great Work, MCPP. Retrieved from http://spdblotter.seattle.gov/ 2018/06/22/getting-ready-for-pride-more-great-work-mcpp/

Quisenberry, P. N. (2001). Television news coverage and its effects on the recording of hate crime. (3028048 Ph.D.), University of Kentucky, Ann Arbor.

Raache, H. (2018). FBI Asked to Assist With Possible Hate Crime In Rogers. Retrieved from https://www.nwahomepage.com/ news/fox-24/fbi-asked-to-assist-with-possible-hate-crime-inrogers-1/1232190892

Shively, M., \& Abt Associates, I. (2005). Study of Literature and Legislation on Hate Crime in America, Final Report. Washington, DC: National Institute of Justice.

Tomei, J., \& Cramer, R. J. (2016). Legal Policies in Conflict: The Gay Panic Defense and Hate Crime Legislation. Journal of Forensic Psychology Practice, 16(4), 217-235. https://doi.org/10.1080/15228932.2016.1192331

Torres-Cortez, R. (2018). Possible hate crime investigated after gay man beaten outside off-Strip resort. Retrieved from https://lasvegassun.com/news/2018/jun/21/possible-hatecrime-investigated-after-gay-man-bea/

Turpin-Petrosino, Carolyn. 2015. Understanding Hate Crimes: Acts, Motives, Offenders, Victims, and Justice: Routledge. https://doi.org/10.4324/9780203883693

Walters, Mark, Rupert Brown and Susann Wiedlitzka. 2016. "Causes and Motivations of Hate Crime." Equality and Human Rights Commission research report 102.

Wong, Jennifer S and Victoria Harraway. 2020. "Media Presentation of Homicide: Examining Characteristics of Sensationalism and Fear of Victimization and Their Relation to Newspaper Article Prominence." Homicide Studies 24(4):333-52 https://doi.org/10.1177/1088767919896391

https://doi.org/10.6000/1929-4409.2021.10.97

() 2021 Collins et al.; Licensee Lifescience Global.

This is an open access article licensed under the terms of the Creative Commons Attribution Non-Commercial License (http://creativecommons.org/licenses/by-nc/3.0/) which permits unrestricted, non-commercial use, distribution and reproduction in any medium, provided the work is properly cited. 